\title{
Detection and quantification of Duffy antigen on bovine red blood cell membranes using a polyclonal antibody ${ }^{1}$
}

\author{
Ana Teresa B.F. Antonangelo², Débora Colombi², Rogério A. Curi², \\ Antonio S.K. Braz ${ }^{2}$, Trícia M. Oliveira ${ }^{4}$ and Lígia S.L.S. da Mota ${ }^{2 *}$
}

\begin{abstract}
Antonangelo A.T.B.F., Colombi D., Curi R.A., Braz A.S.K., Oliveira T.M. \& Mota L.S.L.S. 2012. Detection and quantification of Duffy antigen on bovine red blood cell membranes using a polyclonal antibody. Pesquisa Veterinária Brasileira 32(9):936-940. Departamento de Genética, Instituto de Biociências, Universidade Estadual Paulista Júlio de Mesquita Filho, Unesp-Butucatu, Distrito de Rubião Junior s/n, Botucatu, SP 18618-970, Brazil. E-mail: lmota@ibb.unesp.br

Babesiosis is one of the most important diseases affecting livestock agriculture worldwide. Animals from the subspecies Bos taurus indicus are more resistant to babesiosis than those from Bos taurus taurus. The genera Babesia and Plasmodium are Apicomplexa hemoparasites and share features such as invasion of red blood cells (RBC). The glycoprotein Duffy is the only human erythrocyte receptor for Pasmodium vivax and a mutation which abolishes expression of this glycoprotein on erythrocyte surfaces is responsible for making the majority of people originating from the indigenous populations of West Africa resistant to $P$. vivax. The current work detected and quantified the Duffy antigen on Bos taurus indicus and Bos taurus taurus erythrocyte surfaces using a polyclonal antibody in order to investigate if differences in susceptibility to Babesia are due to different levels of Duffy antigen expression on the RBCs of these animals, as is known to be the case in human beings for interactions of Plasmodium vivax-Duffy antigen. ELISA tests showed that the antibody that was raised against Duffy antigens detected the presence of Duffy antigen in both subspecies and that the amount of this antigen on those erythrocyte membranes was similar. These results indicate that the greater resistance of $B$. taurus indicus to babesiosis cannot be explained by the absence or lower expression of Duffy antigen on RBC surfaces.
\end{abstract}

INDEX TERMS: Babesiosis, cattle, Duffy antigen, hemoparasites.

RESUMO.- [Detecção e quantificação do antigeno Duffy nos eritrócitos de bovinos empregando um anticorpo policlonal.] As doenças infecciosas e parasitárias causam perdas importantes em vários setores da produção da pecuária mundial. Estima-se que mais de 600 milhões de bo-

\footnotetext{
${ }^{1}$ Received on July 22, 2011.

Accepted for publication on May, 15, 2012.

${ }^{2}$ Departamento de Genética, Instituto de Biociências, Universidade Estadual Paulista Júlio de Mesquita Filho (Unesp), Distrito de Rubião Junior s/n, Botucatu, SP 18618-970, Brazil. * Corresponding author: Imota@ibb.unesp.br

${ }^{3}$ Departamento de Melhoramento e Nutrição Animal, Faculdade de Medicina Veterinária e Zootecnia, Unesp-Botucatu, Distrito de Rubião Junior $\mathrm{s} / \mathrm{n}$, Botucatu, SP.

${ }^{4}$ Departamento de Patologia Veterinária, Faculdade de Ciências Agrárias e Veterinárias, Unesp, Rodov. Prof. Paulo Donato Castellane s/n, Jaboticabal, SP 14884-900, Brazil.
}

vinos de países tropicais e subtropicais estejam expostos à infecção por Babesia sp. gerando grande prejuízo econômico. Os gêneros Babesia e Plasmodium são hemoparasitas pertencentes ao filo Apicomplexa e apresentam características comuns no processo de invasão eritrocitária. A babesiose bovina causada por Babesia bigemina e Babesia bovis apresenta sinais clínicos similares a malária humana causada por Plasmodium vivax e Plasmodium falciparum. A glicoproteína Duffy é a única receptora para o $P$. vivax em humanos. A maioria dos indivíduos negros africanos é resistente a este parasita devido a uma mutação que provoca a ausência de expressão desta glicoproteína na superfície das hemácias. Tendo em vista este fato, e que animais da subespécie Bos taurus taurus são mais susceptíveis à babesiose quando comparados à animais Bos taurus indicus, objetivou-se neste trabalho a detecção e quantificação do 
antígeno Duffy na superfície dos eritrócitos de bovinos empregando para tal, anticorpo policlonal que permitisse investigar se as diferenças na susceptibilidade são devido a diferentes níveis de expressão do antígeno Duffy nas hemácias. Ensaios de ELISA mostraram que o anticorpo produzido foi capaz de reconhecer o antígeno Duffy presente nas hemácias bovinas e a análise quantitativa não demonstrou diferença significativa na presença do mesmo. Estes resultados sugerem que a resistência maior dos zebuínos à babesiose não se deve à ausência de expressão, ou à presença em menor quantidade do antígeno Duffy na superfície de suas hemácias.

TERMOS DE INDEXAÇÃO: Babesiose, bovinos, antígeno Duffy, hemoparasitas.

\section{INTRODUCTION}

Babesiosis is one of the most important diseases affecting livestock agriculture worldwide. It is characterized mainly by fever and anemia and is caused by intra-erythrocytic parasites of the genus Babesia (B. bovis, B. bigemina, B. divergens and B. major) (McCosker 1981). In Brazil B. bovis and $B$. bigemina are the causative agents and the tick Rhipicephalus (Boophilus) microplus is the only vector (Paiva-Neto 2004). It is estimated that more than 600 million bovines from tropical and sub-tropical areas are exposed to Babesia spp. causing losses of more than US\$ 1.3 billion a year (McCosker 1981) spent mainly on veterinarian drugs. However, this scenario could change if cheaper and more efficient technologies such as animal breeding for resistance to parasites were used (Santos 2001).

The genera Babesia and Plasmodium belong to phylum Apicomplexa and present similar features such as invasion of host cells (Taylor et al. 1990, Dubremetz 1998, Menard 2001, Cowman \& Crabb 2006), which demands an interaction between a specific receptor on the vertebrate red blood cell (RBC) membrane and a ligand on the parasite surface (Lobo 2005, Yokoyama 2006). Little is known about the molecular interactions between Babesia parasites and their receptors on the bovine host cell surface (Lobo 2005). Cattle infected with B. bigemina and B. bovis present clinical signs very similar to those of human beings infected with Plasmodium vivax and Plasmodium falciparum (Cooke et al. 2005). The glycoprotein Duffy is the only human erythrocyte receptor for Plasmodium vivax (Horuk et al. 1993) and the majority of people originating from the indigenous populations of West Africa are resistant to vivax malaria (Miller et al. 1976, Tournamille et al. 1995) because of a mutation which prevents expression of the Duffy antigen on their erythrocytes' surfaces (Tournamille et al. 1995, Iwamoto et al. 1996).

Considering that Bos taurus taurus are more susceptible to Babesia parasite infection than Bos taurus indicus (Zwart \& Brocklesby 1979, Bock et al. 1999a, 1999b), this work aimed to investigate if the higher resistance of Bos taurus indicus is due to the absence of Duffy antigens or their lower expression on RBC surfaces. To detect and quantify Duffy antigens on erythrocyte surfaces of both subspecies of cattle, a polyclonal antibody against bovine Duffy was produced using a synthetic decapeptide.

\section{MATERIALS AND METHODS}

Animals. Ten eight-week-old female mice from the High IV-A strain (Ibanez et al. 1988) were provided by Bioterium of the Microbiology and Immunology Department, São Paulo State University, Unesp- Botucatu, SP, Brazil.

Blood samples from 30 thoroughbred Bos taurus taurus (15) and Bos taurus indicus (15) animals were from the Experimental Farm São Manuel, Animal Production Department both from Veterinary and Animal Science College, São Paulo State University, Unesp-Botucatu, Central Bela Vista Ltda Farm and Agropecuária W2R Farm located in Pardinho/SP, Brazil. All the procedures involving animals were in agreement with the Brazilian legislation for animal well-being (Protocol 89/2006-CEEA expedited by the Animal Experimentation Ethics Committee (CEEA), of the School of Veterinary Medicine and Animal Science of São Paulo State University, Botucatu/SP, Brazil).

Production of an antiserum against bovine Duffy antigen. The secondary structure of the Bos taurus taurus Duffy protein (GenBank AAX09096.1) was generated at SOSUI (http://bp.nuap. nagoya-u.ac.jp/sosui/cgi-bin/adv_sosui.cgi) (Fig.1), analyzed at HHpred (http://toolkit.tuebingen.mpg.de/hhpred) and Peptide Property Calculator (http://www.innovagen.se/custom-peptide-synthesis/peptide-property-calculator/peptide-property-calculator.asp) for synthetic peptide (YNETDVEAAA) design and preparation. A sequence of ten aminoacids (34 to 43) from N-terminal extracellular region was selected based on its hydrophilicity/antigenicity and synthesized by Invitrogen, USA. The peptide was diluted in sterile milliQ water according to manufacturer's instructions.

Five eight-week-old female High IV-A mice were intraperitoneally (i.p.) immunized with $100 \mu$ g peptide premixed with 100 $\mu \mathrm{L}$ of complete Freund's adjuvant (Difco, USA) $(1: 1, \mathrm{v} / \mathrm{v})$. On days 14 and 28 after the initial immunization, the mice were injected i.p with the same amount of peptide in incomplete Freund's adjuvant $(1: 1, v / v)$. Serum from the immunized mice was collected 10 days after the last booster, pooled and stored at $-20^{\circ} \mathrm{C}$ until use. Five female mice of the same age and strain were not injected and provided pre-immune serum.

Extraction of Red Blood Cell (RBC) membranes. Twenty five milliliters of blood samples from each thoroughbred Bos taurus taurus (15) and Bos taurus indicus (15) animals were collected

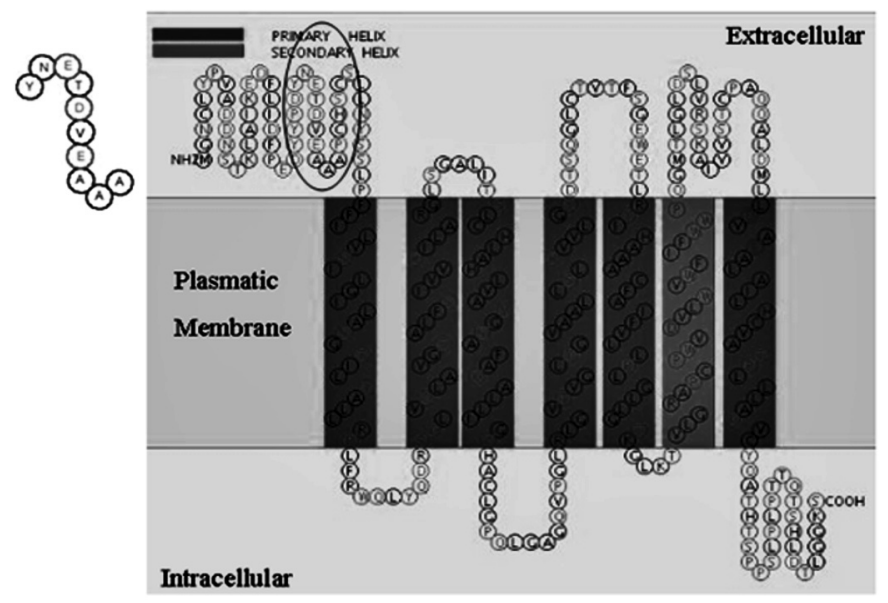

Fig.1. Secondary structure of Bos taurus taurus Duffy protein (GenBankAAX09096.1) created by Sosui server (http://bp.nuap. nagoya-u.ac.jp/sosui/). Detached by the circle: sequence of ten aminoacids YNETDVEAAA (34 to 43) from N-terminal extracellular region. 
in $50 \mathrm{~mL}$ sterile plastic tubes containing $25 \mathrm{~mL}$ of sterile Alsever's solution (113.76 mM glucose, $72 \mathrm{mM} \mathrm{NaCl}, 27.2 \mathrm{mM}$ tri-sodium citrate, $2.8 \mathrm{mM}$ citric acid, $\mathrm{pH} 6.1$ ) and kept on ground ice to chill. The cells were pelleted by centrifugation at $600 \mathrm{xg}$ for 10 minutes at $4^{\circ} \mathrm{C}$. The supernatant was discarded and the erythrocytes were washed three times in $40 \mathrm{~mL}$ of $0.85 \%$ saline solution $(145 \mathrm{mM}$ $\mathrm{NaCl}$ ) with aspiration of the buffy coat. The cells were ressuspended in $35-40 \mathrm{~mL}$ of saline solution and stored at $4^{\circ} \mathrm{C}$ for up to 12 hours before use. Each $10 \mathrm{~mL}$ of erythrocyte suspension was lysed in $90 \mathrm{~mL}$ of Tris- ammonium chloride solution $(170 \mathrm{mM}$ Tris, $11 \mathrm{mM} \mathrm{HCl}, \mathrm{pH} 7.65,155 \mathrm{mM} \mathrm{NH}_{4} \mathrm{Cl}$ ) at $37^{\circ} \mathrm{C}$. The samples were kept in a water bath at $37^{\circ} \mathrm{C}$ for $5-10$ minutes, or until hemolyses occurred, then centrifuged at $11000 \mathrm{xg}$ for 30 minutes at $4^{\circ} \mathrm{C}$. The supernatant was discarded and the white pellets in the bottom which were the ghosts (erythrocyte membranes) were washed twice in $45 \mathrm{~mL}$ of saline solution and centrifuged at $11000 \mathrm{xg}$ for 20 minutes at $4{ }^{\circ} \mathrm{C}$. Pellets were ressuspended in $10 \mathrm{~mL}$ of the following solution $(250 \mathrm{mM}$ sucrose, $1 \mathrm{mM}$ EDTA, $5 \mathrm{mM}$ triethanolamine-HCl, pH 7.5). The amount of protein in the ghosts was estimated by comparison with BSA using Bradford method.

Titration ELISA. The assay was carried out in flat-bottom 96well microtiter plates (MaxiSorp, NUNC, USA) coated overnight at $4^{\circ} \mathrm{C}$ and for $1 \mathrm{~h}$ at $37^{\circ} \mathrm{C}$ with $100 \mu \mathrm{L}$ of peptide $(1 \mu \mathrm{g} /$ well $)$ diluted in a coating buffer $(50 \mathrm{mM}$ carbonate-bicarbonate buffer, $\mathrm{pH}$ 9.6). The plates were washed three times with phosphate buffer saline-Tween 20 (PBST- $136 \mathrm{mM} \mathrm{NaCl}, 2.6 \mathrm{mM} \mathrm{KCl}, 10 \mathrm{mM} \mathrm{Na}_{2} \mathrm{H}-$ $\mathrm{PO}_{4}, 4.2 \mathrm{mM} \mathrm{KH}_{2} \mathrm{PO}_{4}, 0.05 \%$ Tween 20$)$ and blocked (200 $\mu \mathrm{L} /$ well) with $3 \%$ BSA (Amresco, USA) in PBST for $2 \mathrm{~h}$ at $37^{\circ} \mathrm{C}$. Wells from column 1 were treated with $100 \mu \mathrm{L}$ of PBST as a background control. Serum against peptide and pre-immune serum $(100 \mu \mathrm{L} /$ well $)$ were serially diluted $(1 / 50$ to $1 / 6400)$ in $1 \%$ BSA- PBST, incubated for $14 \mathrm{~h}$ at $4^{\circ} \mathrm{C}$ and then for $1 \mathrm{~h}$ at $37^{\circ} \mathrm{C}$. After three washes with PBST, the plates were incubated with alkaline phosphatase conjugated goat anti-mouse IgG serum (KPL, USA) $(100 \mu \mathrm{l} /$ well) diluted to $1: 1000$ in $1 \% \mathrm{BSA}-\mathrm{PBST}$ for $1 \mathrm{~h}$ at $37^{\circ} \mathrm{C}$. The wells were washed as described above and $100 \mu \mathrm{L}$ of substrate solution $(1 \mathrm{mg} / \mathrm{mL}$ of paranitrophenyl phosphate in $9.7 \%$ diethanolamine $\mathrm{pH} 9.8$ ) was then added to each well. After 10-20 minutes of incubation at room temperature (RT), the reaction was stopped by adding $50 \mu \mathrm{L} /$ well of $3 \mathrm{M} \mathrm{NaOH}$ and the absorbance was measured at wavelength $405 \mathrm{~nm}\left(\mathrm{~A}_{405}\right)$ using a microplate reader Multiskan EX (Labsystems Genesis V.3.03). Titer was defined as the highest OD difference between the anti-Duffy antigen serum and pre-immune serum samples with a minimal background (dilutions of $1 / 50$ to $1 / 6400)$. In addition, optimal dilutions of all reagents (peptide, ghosts, anti-Duffy antigen serum and conjugated goat anti-mouse IgG serum) were determined using chessboard titration. Different anti-Duffy antigen dilutions were tested against several peptide and ghosts concentrations in order to detect the best discrimination between the antiserum and the pre-immune serum.

ELISA. The assay was carried out in flat-bottom 96-well microtiter plates (MaxiSorp, NUNC, USA) coated overnight at $4^{\circ} \mathrm{C}$ and for $1 \mathrm{~h}$ at $37^{\circ} \mathrm{C}$ with $100 \mu \mathrm{L}$ of ghost from all the animals separately $(100 \mu \mathrm{g} /$ well) diluted in a coating buffer $(50 \mathrm{mM}$ carbonate-bicarbonate buffer, $\mathrm{pH}$ 9.6). Wells from column 1 were treated with $100 \mu$ l of phosphate buffer saline-Tween 20 (PBST- $136 \mathrm{mM}$ $\mathrm{NaCl}, 2.6 \mathrm{mM} \mathrm{KCl}, 10 \mathrm{mM} \mathrm{Na}_{2} \mathrm{HPO}_{4}, 4.2 \mathrm{mM} \mathrm{KH}_{2} \mathrm{PO}_{4}, 0.05 \%$ Tween $20)$ as a background control. The plates were washed three times with PBST and blocked $(200 \mu \mathrm{L} /$ well) with $3 \%$ BSA (Amresco, USA) in PBST for $2 \mathrm{~h}$ at $37^{\circ} \mathrm{C}$. Serum against peptide and pre-immune serum $(100 \mu \mathrm{L} /$ well) were diluted to $1: 100$ in $1 \%$ BSA-PBST, incubated for $14 \mathrm{~h}$ at $4^{\circ} \mathrm{C}$ and then for $1 \mathrm{~h}$ at $37^{\circ} \mathrm{C}$. After three washes with PBST, the plates were incubated with alkaline phosphatase conjugated goat anti-mouse IgG serum (KPL, USA) $\left(100 \mu \mathrm{l} /\right.$ well) diluted to $1: 1000$ in $1 \%$ BSA-PBST for $1 \mathrm{~h}$ at $37^{\circ} \mathrm{C}$. The wells were washed as described above and $100 \mu \mathrm{L}$ of substrate solution $(1 \mathrm{mg} / \mathrm{mL}$ of paranitrophenyl phosphate in $9.7 \%$ diethanolamine $\mathrm{pH}$ 9.8) was then added to each well. After 10-20 minutes of incubation at room temperature (RT), the reaction was stopped by adding $50 \mu \mathrm{L} /$ well of $3 \mathrm{M} \mathrm{NaOH}$ and the absorbance was measured at a wavelength $405 \mathrm{~nm}\left(A_{405}\right)$ using a microplate reader Multiskan EX (Labsystems Genesis V.3.03). The $A_{405}$ cut-off was set as the mean value of the 24 pre-immune sera plus two standard deviations (S.D.). To show the repeatability of the assay intra-test and inter-test were performed in triplicates.

Blocking ELISA (bELISA). This assay was carried out in flat-bottom 96-well microtiter plates (MaxiSorp, NUNC, USA) coated overnight at $4^{\circ} \mathrm{C}$ and for $1 \mathrm{~h}$ at $37^{\circ} \mathrm{C}$ with ghosts from both subspecies $(100 \mu \mathrm{g} / 100 \mu \mathrm{L} /$ well) diluted in coating buffer $(50 \mathrm{mM}$ carbonate-bicarbonate buffer, pH 9.6). Wells from columns 1 and 2 were treated with $100 \mu \mathrm{l}$ of phosphate buffer saline-Tween 20 (PBST- 136mM NaCl, 2.6mM KCl, 10mM Na2HPO4, 4.2mM KH$2 \mathrm{PO} 4,0.05 \%$ Tween 20 ) as a background control. The plates were

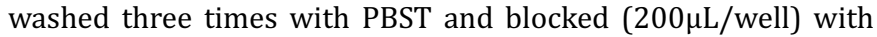
$3 \%$ BSA (Amresco, USA) for $2 \mathrm{~h}$ at $37^{\circ} \mathrm{C}$. In microtubes previously blocked with $3 \%$ BSA (Amresco, USA), $50 \mu \mathrm{L}$ of antiserum and pre-immune serum were diluted 1:100 and mixed with $50 \mu \mathrm{L}$ of serially diluted 2 -fold peptide (5 $\mu$ g initial quantity) in PBST- $1 \%$ $\mathrm{BSA}$, and $100 \mu \mathrm{L}$ of this solution was pipetted into the ghost coated wells ( 8 of these wells were tested with serum samples without peptide solution) and the background wells. Plates were incubated overnight at $4^{\circ} \mathrm{C}$ and then for $1 \mathrm{~h}$ at $37^{\circ} \mathrm{C}$. After three washes with PBST, the plates were incubated with alkaline phosphatase conjugated goat anti-mouse IgG serum (KPL, USA) (100 $\mu \mathrm{l} /$ well) diluted to $1: 1000$ in $1 \%$ BSA-PBST for $1 \mathrm{~h}$ at $37^{\circ} \mathrm{C}$. The wells were washed as described and $100 \mu \mathrm{L}$ of substrate solution $(1 \mathrm{mg} / \mathrm{mL}$ of paranitrophenyl phosphate in 9.7\% diethanolamine $\mathrm{pH}$ 9.8) was then added to each well. After 10-20 minutes of incubation at room temperature (RT), the reaction was stopped by adding $50 \mu \mathrm{L} /$ well of $3 \mathrm{M} \mathrm{NaOH}$ and the absorbance was measured at wavelength $405 \mathrm{~nm}\left(\mathrm{~A}_{405}\right)$ using a microplate reader Multiskan EX (Labsystems Genesis V.3.03). To calculate the percent inhibition of the peptide in blocking assays, the following formula was used: $100-[(T S-B) /(P S-B)] \times 100$. TS denotes the optical density (OD) of the test sample, PS denotes the OD of the pre-immune serum, and $\mathrm{B}$ denotes the background $\mathrm{OD}$.

\section{RESULTS}

A polyclonal antibody against bovine Duffy was produced, in order to detect and quantify Duffy antigens on the erythrocyte surfaces of Bos taurus indicus and Bos taurus taurus, since antibodies against human Duffy antigens cannot recognize bovine proteins which have a different aminoacid sequence mainly at the $\mathrm{N}$-terminal. A synthetic decapeptide (YNETDVEAAA) corresponding to aminoacids 34 to 43 of the N-terminal extracellular domain of the bovine protein (Fig.1) was used to produce in mice an antiserum against bovine Duffy antigen which was titered by ELISA using plates coated with peptide $(1 \mu \mathrm{g} /$ well). The antibody titer of about 1:50, was determined as the highest OD difference between the anti-Duffy antigen serum and pre-immune serum samples with a minimal background (Fig.2). The chessboard result showed that the 1:100 dilution of the anti-Duffy serum was sufficient to detect $100 \mu \mathrm{g}$ of ghost. Antiserum was tested for recognition and quantification of Duffy antigen on bovine RBC surface. The evalu- 
Titration ELISA

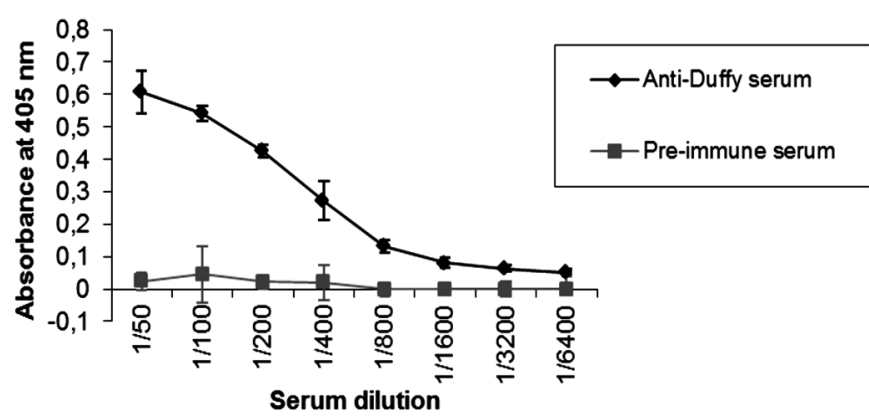

Fig.2. Titration by ELISA of bovine anti-Duffy serum: wells coated with synthetic peptide $(1 \mu \mathrm{g} /$ well $)$ were tested with anti-Duffy and pre-immune serum (from not injected mice) serially diluted (from $1 / 50$ to $1 / 6400)$. Absorbance values $\left(A_{405}\right)$ correspond to differences between serum absorbance values and background values plus standard deviation. The titer (1:50) was considered the highest OD difference between the anti-Duffy antigen serum and pre-immune serum samples with a minimal background.

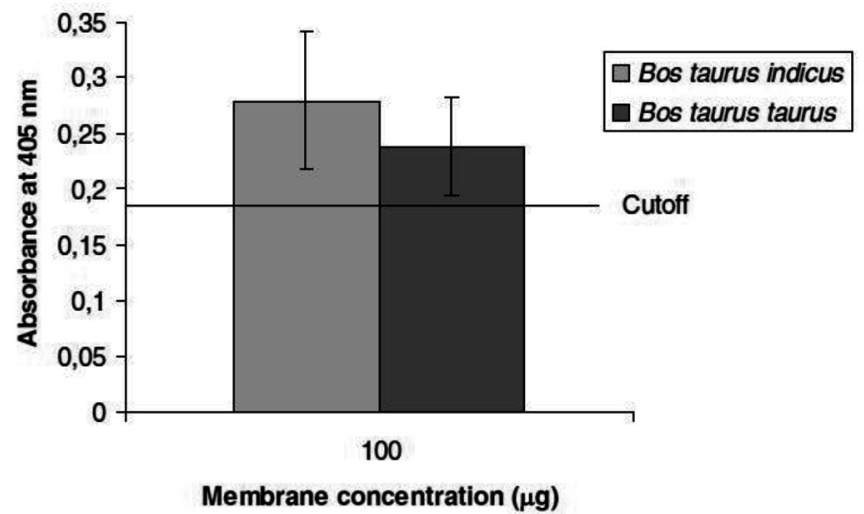

Fig.3. Detection of bovine Duffy antigen in erythrocyte ghosts from $B$. taurus indicus and B. taurus taurus by ELISA in plates coated with $100 \mu \mathrm{g} /$ well of bovine ghosts from both subspecies and tested with antiserum and control serum (1:100). Absorbance values $\left(A_{405}\right)$ correspond to differences between serum samples and background samples. These data are correspondent to 15 experiments of each subspecies. The $A_{405}$ cut-off (0.18) was set as the mean value of 24 control sera plus two standard deviations (S.D.). There is no statistically significant difference between the mean values in the input groups $(P=$ $0,073, t$ - test).

ation of the antiserum specificity was performed by ELISA in plates coated with erythrocyte ghosts from both subspecies. The experiment showed that the raised antibody was specific for bovine Duffy antigen and was capable of recognizing the presence of this antigen both in Bos taurus taurus and in Bos taurus indicus erythrocyte membranes as shown at Figure 3. In order to quantify Duffy antigen in RBC ghosts a blocking ELISA was carried out in plates coated with erythrocyte ghosts $(100 \mu \mathrm{g} /$ well) extracted from blood samples of Bos taurus taurus and Bos taurus indicus. Several dilutions of the synthetic peptide were incubated with bovine antiserum $(1: 100)$ in order to establish the affinity for antigens on RBC ghosts. This assay did not show any significant difference in the amount of Duffy antigen expressed on the erythrocyte membranes from these subspecies $(P=0.073 ; t$-test) (Fig. 4$)$.

\section{bELISA}

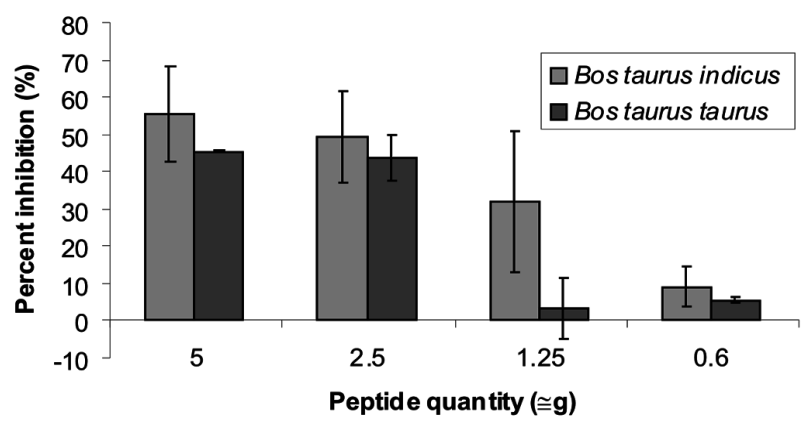

Fig. 4. Quantification of Duffy antigen in erythrocyte ghosts from B.taurus indicus and B. taurus taurus by blocking ELISA. The Duffy antigen present on bovine erythrocyte ghosts (coating wells) competed with several peptide quantities $(5,2.5,1.25,0.6 \mu \mathrm{g})$ for antiserum (bovine anti-Duffy) affinity. Absorbance values at $405 \mathrm{~nm}$ were expressed in Percent Inhibition (PI).

\section{DISCUSSION}

The present data reinforce previous results where differences at Duffy gene transcript levels in animals from Bos taurus taurus and Bos taurus indicus subspecies could not be observed. According to Carvalho et al. (2009) although single nucleotide polymorphisms (SNPs) were found between Bos taurus taurus and Bos taurus indicus breeds in the Duffygene promoter region, no difference was observed in Duffy mRNA level produced in the bone marrow of both subspecies.

Although these findings suggest that the difference between these bovine subspecies related to babesiosis resistance/susceptibility cannot be explained by the differential expression or levels of expression of Duffy antigen on erythrocyte surfaces, some changes in the DNA coding sequence region could be responsible, nevertheless. In human beings the Duffy antigen aminoacid shifting G44D defines two phenotypes (Fy and $\mathrm{Fy}^{\mathrm{b}}$ ) (Iwamoto et al., 1996) but does not confer any Plasmodium vivax resistance (Miller et al. 1976); however, a single aminoacid substitution (R89C) reduces by $90 \%$ the level of Duffy protein detected on the erythrocytes (Olsson et al. 1998, Tournamille et al. 1998) which reduces it ability to bind to chemokines and therefore possibly might confer certain resistance to $P$. vivax infection (López et al. 2010). The alignment of Bos taurus taurus and Bos taurus indicus Duffy protein sequences deposited at the GeneBank shows $99 \%$ identity and just the changes at the aminoacid 22 (F22L) are exclusive of Bos taurus indicus which could have a role in babesiosis resistance.

\section{CONCLUSION}

The antibody raised was specific to bovine Duffy antigen and was capable of recognizing the presence of this antigen in Bos taurus taurus and in Bos taurus indicus erythrocyte membranes. However, the results of the present work suggest that, unlike in indigenous West African populations with respect to malaria, the greater resistance of $B$. taurus indicus to babesiosis cannot be explained by the absence or lower expression of Duffy antigen on their RBC surfaces.

Acknowledgements.- The authors would like to thank Professor Rosângela Zacarias Machado for technical support and Coordenação de Aperfeiçoamento de Pessoal de Nível Superior (CAPES) for financial support. 


\section{REFERENCES}

Bock R.E., Kingston T.G. \& De Vos A.J. 1999b. Effect of breed of cattle on transmission rate and innate resistance to infection with Babesia bovis and B. bigemina transmitted by Boophilus microplus. Aust. Vet. J. 77:461464.

Bock R.E., Kingston T.G., Standfast N.F. \& De Vos A.J. 1999a. Effect of cattle breed on innate resistance to inoculations of Babesia bigemina. Aust. Vet. J. 77:465-466.

Carvalho T.L., Ribolla P.E.M., Curi R.A. \& Mota L.S.L.S. 2009. Characterization and transcriptional analysis of the promoter region of the Duffy blood group, chemokine receptor (DARC) gene in cattle. Vet. Immunol. Immunopathol. 132:153-159.

Cooke B.M., Mohandas N., Cowman A.F. \& Coppel R.L. 2005. Cellular adhesive phenomena in apicomplexan parasites of red blood cells. Vet. Parasitol.132:273-295.

Cowman A.F. \& Crabb B.S. 2006. Invasion of Red Blood Cells by malaria parasites. Cell 124: 756-766.

Dubremetz J.F. 1998. Host cell invasion by Toxoplasma gondii. Trends Microbiol. 6:27-30.

Horuk R., Chitnis C.E., Darbonne W.C., Colby T.J., Rybicki A., Hadley T.J. \& Miller L.H. 1993. A receptor for the malaria parasite Plasmodium vivax: the erythrocyte chemokine receptor. Science 261:1182-1184.

Ibanez O.M., Mouton D., Oliveira S.L., Ribeiro Filho O.G., Piatti R.M., Santanna O.A., Massa S., Biozzi G. \& Siqueira M. 1988. Polygenic control of quantitative antibody responsiveness: Restrictions of the multispecific effect related to the selection antigen. Immunogenet. 28:6-12.

Iwamoto S., Li J., Sugimoto N., Okuda H. \& Kajii E. 1996. Characterization of the Duffy gene promotor: evidence for tissue-specific abolishment of expression in Fy(a-b-) of black individuals. Biochem. Biophys. Res. Commun. 222:852-859.

Lobo C.A. 2005. Babesia divergens and Plasmodium falciparum use common receptors, glycophorins A and B to invade the human red blood cell. Infect. Immun. 73:649-651.

López C., Saravia C., Gomez A., Hoebeke J. \& Patarroyo M.A. 2010. Mechanisms of genetically-based resistance to malaria. Gene 467:1-12.
McCosker P.J. 1981. The global importance of babesiosis, p.1-24. In: Ristic M. \& Krier J.P. (Eds), Babesiosis. Academic Press, New York.

Menard R. 2001. Gliding motility and cell invasion by Apicomplexa: insights from the Plasmodium sporozoite. Cell Microbiol. 3:63-73.

Miller L.H., Haynes J.D., Mccauliffe I.M., Shiroishi T., Durocher J.R. \& McGinniss M.H. 1976. Evidence for difference in erythrocyte surface receptors for malarial parasites Plasmodium falciparum and Plasmodium knowlesi. J. Exp. Med. 146:277-281.

Olsson M.L., Smythe J.S., Hansson C., Poole J., Mallinson G., Jones J., Avent N.D. \& Daniels G. 1998. The $\mathrm{Fy}^{\mathrm{x}}$ phenotype is associated with a missense mutation in the Fy ${ }^{b}$ allele predicting Arg89Cys in the Duffy glycoprotein. Brit. J. Haematol. 103:1184-1191.

Paiva-Neto M.A. 2004. Estudo da incidência e localização de carrapato (Boophilus microplus) em bovinos nelore, holandês e curraleiro no Distrito Federal. Circular Técnica Embrapa 34:10-35.

Santos I.K.F.M. 2001. Polimorfismo do sistema imunológico e sua aplicação no melhoramento animal para resistência a doenças infecciosas e parasitárias, p.41-60. In: Regitano L.C.A. \& Coutinho L.L. (Eds), Biologia molecular aplicada à produção animal. Embrapa Informação Tecnológica, Brasília. 215p.

Taylor D.W., Evans C.B., Aley S.B., Barta J.R. \& Danforth H.D. 1990. Identification of an apically located antigen that is conversed in sporozoan parasites. J. Euk. Microbiol. 37:540-545.

Tournamille C., Colin Y., Cartron J.P. \& Le Van Kim C. 1995. Disruption of a GATA motif in the Duffy gene promoter abolishes erythroid gene expression in Duffy-negative individuals. Nature Genet. 10:224-228.

Tournamille C., Le Van Kim C., Gane P., Le Pennec P.Y., Roubinet F., Babinet J., Cartron J.P. \& Colin Y. 1998. Arg89Cys Substitution results in very low membrane expression of the Duffy antigen/receptor for chemokines in Fy'Individuals. Blood 92:2147-2156.

Yokoyama N., Okamura M. \& Igarashi I. 2006. Erythrocyte invasion by Babesia parasites: Current advances in the elucidation of the molecular interactions between the protozoan ligands and host receptors in the invasion stage. Vet. Parasitol. 138:22-32.

Zwart D. \& Brocklesby D.W. 1979. Babesiosis: non specific resistance immunological factors and pathogenesis. Adv. Parasitol. 17:49-112. 